\title{
V. NEMZETKÖZI INTERDISZCIPLINÁRIS KONFERENCIA (BESZÁMOLÓ)
}

\section{Szerző:}

Mező Ferenc (PhD)

Kocka Kör

Mező Katalin (PhD)

$\mathrm{K}+\mathrm{F}$ Stúdió Kft.

Szerző e-mail címe:

ferenc.mezo1@gmail.com

\section{Lektorok:}

Csibi Sándor (PhD)

Marosvásárhelyi „George Emil

Palade” Orvosi, Gyógyszerészeti, Tudomány és Technológiai Egyetem

(Románia)

\author{
K. Nagy Emese (PhD) \\ Eszterházy Károly Egyetem
}

...és további két anonim lektor

\section{Absztrakt}

Jelen összefoglaló az V. Nemzetközi Interdiszciplináris Konferenciát mutatja be. Tekintettel a COVID-19 (koronavírus-betegség) járványának kockázatára, ez a konferencia e-konferenciaként valósult meg, személyes jelenlét nélkül.

Kulcsszavak: konferencia, interdiszciplináris, nemzetközi

Diszciplina: interdiszciplináris

\section{Abstract}

V. INTERNATIONAL INTERDISCIPLINARY CONFERENCE (SUMMARY)

Present summary shows on the $\mathrm{V}$. International Interdisciplinary Conference. Given the risk of the epidemic of COVID-19 (Coronavirus disease), this conference was realized as an e-conference without a personal presence.

Keywords: conference, interdisciplinary, international

Discipline: interdiscilinary

Mező Ferenc és Mező Katalin (2020): V. Nemzetközi Interdiszciplináris Konferencia (Beszámoló). OxIPO - interdiszciplináris tudományos folyóirat, 2020/1, 59-70. doi: 10.35405/OXIPO.2020.1.59 
A mesterséges intelligenciától a rákkutatáson és az ûrkutatáson át a pedagógiáig terjedt az előadások témája az V. Nemzetközi Interdiszciplináris Konferencián, ahol 16 ország 274 résztvevőjének 202 előadása fókuszált az említett témákra (1. ábra).

1. ábra: az V. Nemzetközi Interdiszciplináris Konferencia sámokban (forrás: a Szuerzoók)

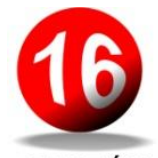

ORSZÁG

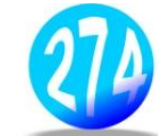

RÉSZTVEVŐ

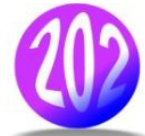

PREZENTÁCIÓ
A 2. ábra mutatja be a rendezvény tágabb résztvevői körét országonként, illetve szûkebb szervezői körét.

2. ábra: az V. nemzetközi Interdiszciplináris Konferencia résztvevooi (országonként) és szervezôii köre (forrás: a Szerzóke)

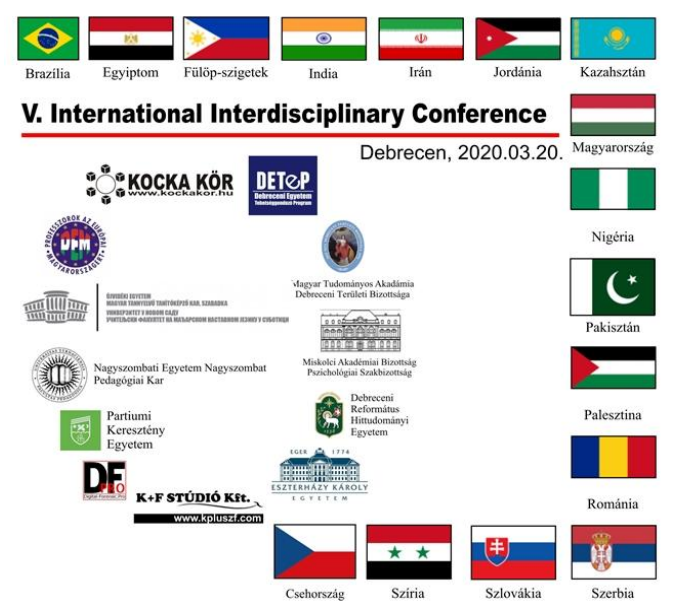

A rendezvény főszervezője: a Kocka Kör Tehetséggondozó Kulturális Egyesület; képviseli: Dr. Mező Ferenc, a Kocka Kör elnöke, a rendezvény alapítója.

Társszervezők (zárójelben a rendezvény által a konferenciabizottságba delegált képviselő neve):

- Debreceni Egyetem Tehetséggondozó Programja (Drs. Mándy Zsuzsanna),

- Debreceni Református Hittudományi Egyetem (Dr. Németh Áron),

- Digital Forensic Pro (Marian Svetlik),

- Eszterházy Károly Egyetem (Dr. Mező Ferenc),

- Magyar Tudományos Akadémia Debreceni Akadémiai Bizottság (Magyar Éva),

- MTA Miskolci Akadémiai Bizottság, Pszichológiai Szakbizottság (Dr. Hanák Zsuzsanna),

- Nagyszombati Egyetem (Dr. Ildikó Psenáková),

- Partiumi Keresztény Egyetem (Dr. Gál Katalin),

- Professzorok az Európai Magyarországért Egyesület (Dr. Koncz István),

- Újvidéki Egyetem (Dr. Horák Rita), - K+F Stúdió Kft. (Dr. Mező Katalin).

Tekintettel a COVID-19 (koronavírusbetegség) járványának kockázatára, a rendezvény e-konferenciaként valósult meg, személyes jelenlét nélkül. Ez gyakorlatilag azt is jelenti, hogy az eredetileg tervezett 2020.03.20-i dátum helyett, 2020.03.15-tôl 2020.05.01-ig terjed a konferencia időszaka (az egy napra tervezett rendezvény így másfél hónapon át tartó rendezvénnyé vált) a 3. ábrán látható forgatókönyv szerint. 


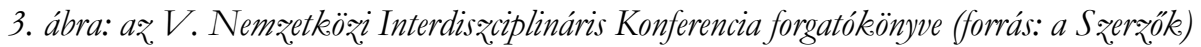

THIS E-CONFERENCE HAS FIVE PHASES. THESE ARE:

PHASE $1:$

UPLOADING .PPT, .MP4 etc. PRESENTATIONS

Date: from 15 March 2020 to 19 March 2020

Activities:

1) Participants upload their files through this form.

2) Organizers send conference certification to the participants

PHASE 2:

PERIODIC PUBLISHING

OF .PPT, .MP4 etc. PRESENTATIONS

Date: from 20 March 2020 to 1 Apr 2020

Activities:

1) Those who interested can download the presentations through this form.

2) Those who interested can ask public questions and give public suggestions to Authors by this form. Questions and suggestions will be collected into a database.

3) Organizers send the questions and suggestions to addressees until 1 Apr 2020.

PHASE 3:

CREATING PUBLIC ANSWERS

Date: from 1 Apr 2020 to 15 Apr 2020.

Activity: Participants send the answers to

Organizers. Deadline is 15 Apr 2020.

PHASE 4

PUBLISHING THE ANSWERS

Date: from 16 Apr 2020 to 1 May 2020 ,

Activity: the answers will be available through this

form.
PHASE 5:
CLOSING OF THIS CONFERENCE

Date: 2 May 2020

Activity: Organizers archive the files and turn off this

form.

UPLOADING STUDIES:

Date: from 15 March 2020 to 1 May 2020.

Activity: Participants upload their studies through this form.

By submitting this study, the Author contributes to the publication of the study in one of the following journals or edited book in 2020: OxIPO

Mesterséges intelliegencia /Artificial Intelligence/, Lélektan és hadviselés /Psychology and Warfare/, A világ interdiszciplináris megközelítésben /The World from Interdisciplinary Approach-2020/

\section{AZ E-KONFERNCIÁNAK ÖT FÄZISA VAN. EZEK:}

\section{FÁZIS:}

15 March

19 March

$01 \mathrm{Apr}$

$01 \mathrm{Apr}$

$15 \mathrm{Apr}$

$16 \mathrm{Apr}$

01 May 02 May
A .PPt, MP4 stb. PREZENTÁCIÓK FELTÖLTÉSE

Dátum: 2020. márc. 15 - 2020. márc. 19.

Tevékenységek:

1) A résztvevők feltöltik a fájlokat ennek az ürlapnak a segítségével

2) A szervezök elküldik a konferencia-igazolásokat a résztvevöknek

\section{FAZZIS:}

A .PPT, .MP4 stb. PREZENTÁCIOKK IDÓSZAKOS KÖZZĖTÉTELE

Dátum: 2020. márc. 20, - 2020, ápr. 1.

Tevékenységek:

1) Az érdeklōdök letölthetik a prezentációkat jelen ürlap révẻn

2) Az érdeklödōk nyilvánosan kérdezhetnek, javasolhatnak jelen ûrlap révén. A kérdéseik és a javaslataik egy adatbázisba lesznek összegyüjtve.

3) A szervezök elküldik a cimzetteknek a kérdéseket és a javaslatokat 2020. ápr. 1-ig.

\section{FÁZIS:}

NYILVÁNOS VÁLASZOK ALKOTÁSA

Dátum: 2020. ápr. 1, - 2020. ápr. 15.

Tevékenység: A résztvevök elküldik a válaszukat a szervezōknek. Határidö: 2020. ápr. 15.

\section{FÄZIS:}

VÁLASZOK NYILVANOSSÁ TÉTELE

Dátum: 2020. ápr. 16, - 2020, máj. 1.

Tevékenység; a válaszok olvashatók lesznek ezen az ürlapon keresztül.

\section{FÄZIS:}

A KONFERENCIA ZÁRÁSA

Dátum: 2020. majus 2.

Tevékenység: a Szervezök archiválják a fájlokat és kikapcsolják ezt az ürlapot.

\section{TANULMÁNYOK FELTÖLTÉSE:}

Dátum: 2020. márc.15, - 2020. mảj. 1.

Tevékenység: a Résztvevớk feltöltik a tanulmányaikat ezen az ürlapon keresztūl.

A tanulmány beküldésével a Szerzö hozzájárul, hogy a mũ az alábbi kiadványok egyikében 2020. ban megjelenjen: OxIPO, Mesterséges intelligencia, Lélektan és hadviselés, A világ interdiszciplinárlis megközelitésben - 2020. 
A prezentációk megtekinthetők az alábbi linken, az „I would like to get to know the uploaded presentations. / Szeretném megismerni a feltöltött prezentációkat" opció választásával:https://docs.google.com/forms/ d/e/1FAIpQLScwZNW4Hcb-1sAQboCwPj GIJCJKYAnKMIqI4ddl8qoTgmPc7A/viewf orm

Társadalmi felelősségvállalási tevékenység formájában a rendezvényt három új tudományos, Open Access e-folyóirat is támogatja, ezek (4. ábra): Lélektan és hadviselés, Mesterséges intelligencia és OxIPO (közös elosztó oldaluk. E folyóiratok közös elosztóoldala: http://www.kpluszf.com/KFS folyoiratok.h tml. Olyan témák esetében, amelyek nem illeszkednek e lapok profiljához a szervezők etanulmánykötetet adnak ki 2020-ban.

A tudományági sokszínűség közötti összekötő kapocsként (a konferenciasorozat elôző négy alkalmához hasonlóan) az idén (a konferenciát követő nyilvános kérdésfeltevési szakaszban) is azt kérték a szervezők az előadóktól, hogy legalább egy gondolat erejéig villantsák fel, hogyan kapcsolódik saját előadásuk a szervezők által megadott átfogó témakörökhöz. Az idei témakörök:

• „Humán élet a Földön kívül”,

- „Lélektan és hadviselés”,

- a humán információfeldolgozás hatékonyságának fokozását célzó kutatásokat öszszefogó „OxIPO” elv, illetve

• „Mesterséges intelligencia”.

A kérdésekre adott válaszokat a jövőben a 4. ábrán említett lapok hasábjain teszik közzé a szervezők.
4. ábra: a rendezvényt támogató folyóiratok (forrás: a Szerzőo)
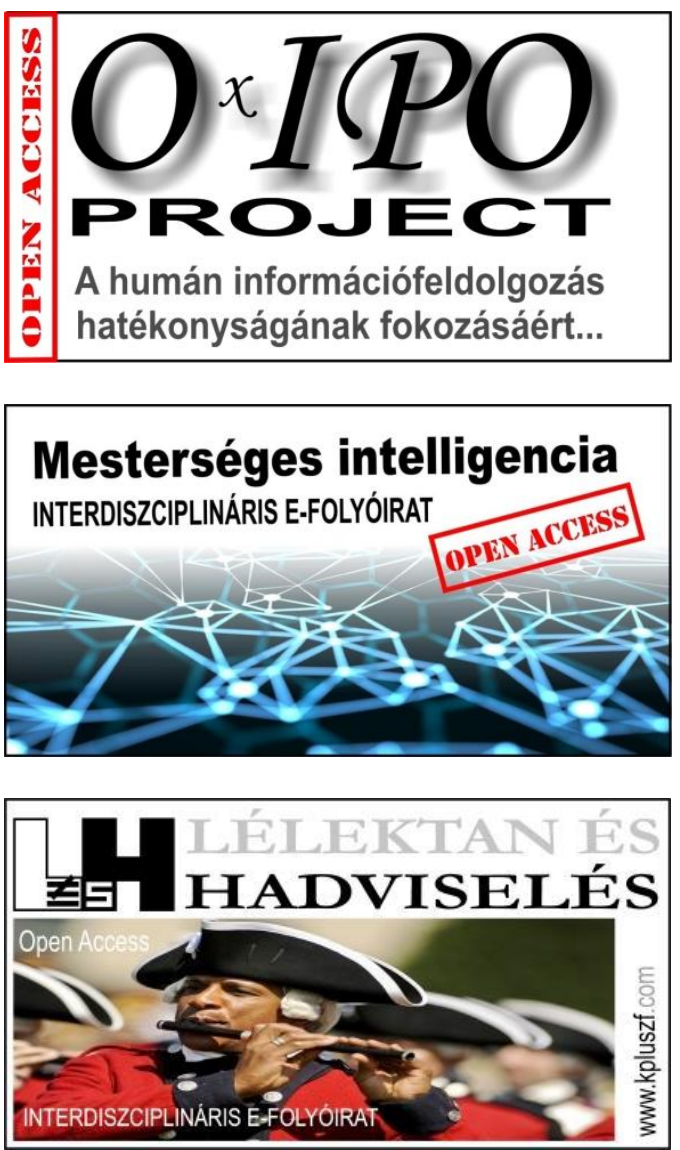

A konferencia interdiszciplináris jellegét tükrözi a szekciók, az előadók és prezentáció címek listája is (lásd: ezeket lásd a következő oldalakon).

A szervezők nevében mindenkit várunk tisztelettel a 2021. márciusában megrendezésre kerülő VI. Nemzetközi Interdiszciplináris Konferencián! Erről bővebb információ az OxIPO folyóirat 2020/4. számában lesz közreadva 2020. decemberében. 
Szekciók, előadók és prezentációk:

Section I. / I. Szekció :

HEALTH AND MEDICINE 1 / EGÉSZSÉG ÉS ORVOSTUDOMÁNY 1.

Chairman / Szekcióvezető:

Koncz Hajnalka Anna

Abuhajiar, Salim, Margit, Balazs and Szász, István: Protein Expression Pattern associated with Resistance of Targeted Combination Therapy in Melanoma Cell Lines

Angeli Csenge: Multiprofesszionális rehabilitációs team kommunikációjának mérési lehetöségei

Atalah, Hadeer and Pfliegler, Walter P.: Genetic and phenotypic investigation of antimycotic resistance in probiotic yeasts

Bajtek, Beáta: Examining the connection between the characteristics of GP practices and patients' satisfaction with health care

Baksa Viktória, Ujlaki Evelin, Tóth Dominika Adelina és Szigeti-Turáni Melinda: Szén nanocsövek aggregáciojjának hatásai a cornea regenerációja során

Barth Anita, Kállay Márk és Nemes Balázs: Veseátültetésre vonatkozó, szakmai döntéshozást támogató online konzultációs rendszer regionális vizsgálata veseelégtelenségben szenvedö betegek körében

Bencs Viktor: Lemur tirozin-kináz 2 expresszió virsgálata tauopathiákban

Bihari Kitti: Agyéki gerincszakaszt érintố degenerativ gerincbetegségek kezelése az. Evminovmódszerrel

Bói Bernadett: Egészségügyi ellátással kapcsolatos elégedettség vizsgálata krónikus betegségben szenvedók körében

Cs. Szabó Bence: A C16-ceramid és C16glikozilceramid Kv1.3 ioncsatorna membránbeli lokalizációjára és kapuqására kifejtett hatásainak vizsgálata

Csontos Fruzsina: Az alsó végtag sérülésmintái és izomnyújthatósági vizsgálata labdarúgók és vizilabdázók körében

Duruczné Téglás Dóra: Kríziskommunikáció a Magyar Honvédség aspektusai

Egu, John, Kalmár, József and Király, Gabor: Controlled release of Methotrexate from functionalized Silica-gelatin Aerogel Microparticles applied against Tumor Cell Growth

Fehér Ádám: TRPA1 ioncsatorna modulátorainak vizsgálata

Greff Dorina: Nem invaziv DNS alapú prenatális tesztek a klinikai gyakorlatban

Gyenes Dominik: Csökekent izomregeneráció Mer Tirozin Kináz hiányos egér modellben

Handlery, Anna: The Right to Life in the European Convention on Human Rights and Fundamental Freedoms

Hegedűs Réka és Szerdi Márta: Fiatalok szexuális magatartásának vizsgálata gimnáziumban tanuló fiatalok körében - egy virsgálat kezdeti eredményei

Hinnah Barbara: TGF- $\beta$ útvonal változása Alzbeimer-kórban

Kabai Péter: Akut májelégtelenség alternativ kezelési módjai

Kádár Rebeka: Pacing indukálta cardiomyopathia bátterében álló jobb kamrai funkciót és mechanikát leiró paraméterek vizsgálata 3D echokardiográfiával

Karikás Tamara Beáta: A Népegészségügyi ellenôr szakos hallgatók kiégésének vizsgálata

Keserű Judit Szilvia, Soltész Beáta, Jenei Adrienn, Németh Nikolett, Szirák Krisztina, Klekner Álmos Péter és Nagy Bálint: Mitokondriális DNS kópiaszámának kimutatá- 
sa glioblastomás betegek plazmájából izolált exoszómákban

Koncz Anna Hajnalka: PET-CT bibrid képalkotás szerepe tüdő és fej-nyak tumorok $N$ és $M$ klinikai stagingjében

Kovács Szonja Anna: A smoothelin-szerü fehérje 1 inzulinérzékenyitó szerepe a vázizomban

László Loretta és Lengyel Máté: DEPP fehérje biológiai funkciójának vizsgálata az emlörák megelōrésében

Section II. / II. Szekció :

HEALTH AND MEDICINE 2 / EGÉSZSÉG ÉS ORVOSTUDOMÁNY 2.

Chairman / Szekcióvezető:

Koncz Béla Norbert

Lengyel Máté és László Loretta: ZG16B fehérje hatása normál emló epitheliális sejtek migrációjára és proliferációjára

Lepp Kitti és Némethné Gyurcsik Zsuzsanna: Scapularis diszfunkció és a törzs-alsóvégtag stabilitásának vizsgálata, intervenciója a kosárlabdárók körében

Lukács Luca: Perifériás fehérvérsejtek fagocita funkcióinak vizsgálata plazmakisérletek által endometriózisban szenvedö nökben mütét elött és után

Madai Alexandra: A gyógyszereke és gyógynövények fogyasztási szokásainak vizsgálata

Márkus Anna: Tartáskorrekciós mozgásterápia hatásainak felmérése óvodás korú gyermekek körében

Mehrabanian, Mojtaba and Juhász, Alexander: Engine-driven rotary endodontics enlargement systems evaluation using micro $C T$
Molnár Judit és Szikszai Renáta: $A$ háziorvos életkorának hatása a diabetes gondozás minöségére

Nadra Alzain: Mechanisms of Gene Regulations in Macrophages

Nkiruka, Anioke Blessing: Digital Technology for Cancer Patients

Ocsenás Dorottya: Biológiai nem és társadalmi nem szerinti sajátosságok a hosszú távra szóló párválasztással kapcsolatos attitüdökeben

Palánkay Dóra: Egészségattitüd és káros sqokások mértékének vizsgálata középiskolás diákok körében

Papp Szabolcs: Influenza elleni védöoltás igénybevételének vizsgálata magyarországi és szerbiai COPD-s betegek körében az. Európai Lakossági Egésaségfelmérés adatai alapján

Polyák Lenke: Újonnan szintetizált nukleozid analógok citotoxikológiai vizsgálata

Rashed Muhsen and Marcell Clemens: Validation of the bogossian formula in the prediction of the modified qt interval in left bundlebranch block

Simó Ferenc Zoltán: Right to life in Hungary and in the EU: the ever-troublesome issue of abortion

Szabó Máté, Zákány Florina, Varga Zoltán és Kovács Tamás: Szterolok és többszörösen telitetlen zsirsavak dipólpotenciálra gyakorolt hatásának tesztelése új áramlási citometriás módszerrel

Szerdi Márta és Hegedűs Réka: Squiv-és érrendszeri megbetegedések közösségre iráyuló prevenciója: fókuszban a stroke

Szikszai Renáta és Varga Kincső: A preventív fogászati kezelések igénybevételét befolyásoló tényerók vizsgálata Magyarországon

Szinay Dorottya: Effects of Rituximab in patients with idiopathic inflammatory myopathies 
Szőke Zsombor, Simkó Attila és Veres Szilvia: A növény cink hasznositás szerepe a fóbb élettani folyamatok befolyásolásában

Szőllősi Gergő József: Az influenza elleni átoltottság vizsgálata Magyarországon COPD-s betegek körében

Szőllősi Gergő József: Debreceni Egyetem ötödéves orvostanhallgatóinak tudása és hozzáállása az. elhizással kapcsolatban

Szőnyi Krisztina és Tuza Alexandra: Az egészségmüveltség és a táplálkozási szokások közötti összefüggés vizsgálata serdülők körében

Varga Kincső és Molnár Judit: A háziorvosok egyéni jellemzôi és a mammográfiás szürés igénybevétele kö̈ö̈tti kapcsolat a hazai alapellátásban

Wilisicz Ticián: A BGP-15 kismolekulás bidroxámsav származék kardiovaszkuláris hatásai

Zsigrai Emese, Kovács Patrik, Matta Csaba és Hajdú Tibor: Sejtfelszini biomarkerek azonositása bumán pigmentsejteken

Section III. / III. Szekció :

ENVIRONMENT / KÖRNYEZET

Chairman / Szekcióvezető:

Szatmári Roland és Tóth Ákos

Abid, Areha: Development of food prototype with sour cherry and chocolate with anti-inflammatory properties

Adeniyi, Odunayo David and Szabo, Andrea: Wheat yield forecasting for Karcag region using Landsat and Modis Satellite remote sensing Data

Alamaireh, Mohammad and Benedek, Andrea: Environmental awareness for sustainability
Firak, Daniel Scheres , Krasznahorkay, A.J., Csatlós, M., Csige, L., Gulyás, J., Koszta, M., Szihalmi, B., Timár, J., Nagy, Á., Sas, N.J. and Krasznahorkay, A.: X17: the search for a new particle (and how scientist at MTA Atomki may have found it)

Gergely Virág, Salma Imre, Varga Tamás, Major István, Futó István és Molnár Mihály: Aeroszol minták stabil C-N-S izotóp vizsgálata

Jánosy Orsolya: International Mobility of Researchers

Jónás Andrea Petra: Az Aspergillus fumigatus bumánpatogén gombafaj szénstressz. válaszainak vizsgálata transžkriptomikai módszerekekel

Kalmár Gréta, Jevcsák Szintia és Máthé Endre: Növényi kivonatokekal dúsitott csokoládé fejlesztés

Khamitova, Madina, Csoma, Hajnalka és Dályai, Livia: Examination of genes responsible for the pulcherrimin synthesis in Metschnikowia fructicola mutant strains

Kis Szabolcs: A tájszerkeezet hatása az agrártáj élöhelyszigeteinek vegetációjára

Kushwahaa, Tanya: Temperature variations in star forming interstellar cores

Lamee, Zeinab and Fodor, Szilvia: Validating the influence of students' emotions on their engagement

Macagga, Reena: Ammonium Nitrogen Adsorption Capacity and Soil Leaching Kinetics Study of Slow-Release Fertilizers from Rice Husk Ash

Máté Ádám, Murányi Eszter, Zsembeli József és Veres Szilvia: Szemes cirok (Sorghum bicolor (L.) Moench) genotipusok környezeti igényeinek összehasonlitó elemzése 
Nagy, Sarolta: Work Simulators' place in OSHA, in case of Persons with Disability Methodology Developing

Szalacsi Norbert és Veres Szilvia: Ví̧̧iány stressz hatása lucerna genotipusok csírázási és vegetativ jellemzöire

Szatmári Roland: Száradásos repedezés vizsgálata

Tóth Ákos: A 95Ru és 95Tc izotópok felezési idejének meghatározása gamma-spektroszkópiával

Uzonyi Noémi: An empirical study of Taylor's power law in random graph models and real networks

Vuk Aliz: Odvas keltike (Corydalis cava L.) és ujjas keltike (Corydalis solida L.) állományának vižsgálata a Nagycserei Körises Arborétumban

\section{Section IV. / IV. Szekció :}

PEDAGOGY, RELIGION AND SOCIETY / PEDAGÓGIA, VALLÁS ÉS TÁRSADALOM

Chairman / Szekcióvezető:

Szalacsi Norbert

Almási Brigitta: Szemelvények a Cegléd környéki tanyai iskolák életéböl

Almási, Brigitta: Biographies of the farm schools near Cegléd between 1940 and 1960

Apró Anna: A fényszennyezés hazai és nemzetközi kutatási problémái, eredményei a neveléstudományban

Balázs Dóra és Vas János: Debreceni Egyetem osztatlan tanárszakos hallgatóinak pályaorientációs vizsgálata az elmúlt három évben

Béni Brigitta Anett: $A$ bit és a biedelem szerepe egy település kulturális életében

Bodnár Noémi: Hogyan készül egy jelnyelvi (szleng)szótár?
Borsos Éva és Horák Rita: A vajdasági magyar ajkú fiatalok szabadidôs tevékenysége

Éliás János: A nagykunsági partikulák, mint alsóbb iskolák szerepe a Debreceni Református Kollégium oktatási rendszerében 1588-tól 1850-ig

Józsa, Barbara: The Representation of Trauma in Tracey Emin's Art

K. Nagy, Emese: Development of Low status Roma Students in a Heterogeneous Group of Students in Terms of Knowledge and Socialization

Kiss Anita: Kódváltási szokások és hozzá kapcsolódó attitüdök vizsgálata kárpátaljai magyar egyetemisták körében

Koncz Anna Hajnalka és Koncz Béla Norbert: Reformáció hatása a medicinára

Kovács Zsófia Dóra: Erényelméletek, avagy viszszatérés Arisztotelészhez az itélkezéselméletben

Kozma Kitti: Reziliens életúttal a pedagógus pályán

Krisztán, Daniella: Confined Spaces: Reading the Girl Experience in Short Stories by Arab Women Writers

Kuszinger, Rebeka: Storytelling as a Means of Atonement: Adaptation Method's of a Confession Ian McEwan's Atonement

Magyar Balázs Dávid: A paráználkodás (egyház)jogi megitélése Debrecenben 1547-1625.

Mándoki Réka: Idegen nyelv megjelenése az óvodában

Nagy Dávid Krisztián: A kora újkori gyülekęeti énekek komplex elemrése

Nemes Magdolna: A kétnyelvüvé válás nehézségei

Nemes-Zámbó Gabriella: A társadalmi státusz. és a lokális oktatás összefüggései egy rurális településen

Oláh Eszter: Társadalmi alapjövedelem a hazai tudományban - Anomália vagy realitás? 
Pálfi Dorina: A pedagógusok fejlesztését végző trénerek nehézségeinek, informálódási lehetöségeinek feltárása

Polgáriné Szilágyi, Edit: Fatherlessness and Masculanity in Kate Atkinson's Bebind the Scenes at the Museum

Reszeginé Vályogos Krisztina: Magyarország népességének iskolázottsági mutatói (1970-2016)

Roszik Dóra: A vizsgaszorongás mértéke az alkalmazott tanulási stratégiák viszonylatában

Sáfrány Judit: Szorongásos tünetegyüttes az iskolai környezetben

Sáfrány, Judit: Anxiety disorders and academic achievement

Sasné Venczel Ildikó: Minden NA(p)T -i problémák, (jó) gyakorlati válaszok.

Sebestyén Krisztina: Az általános iskolai idegennyelv-választás jellemzôi

Szabó Dóra: Fake news és a leendō pedagógusok

Szávó Andrea: Language Transfer in Third Language Acquisition

Szűcs Enikő: Felsőoktatási intézmények szerepe a szociális szakemberképzésben

Tolnai Tímea Katalin: A papmarasztás és lelkészuálasztás bihardiószegi története

Tudlik Csilla: Bizonytalanság, hatékonyság és pályaérdeklödés

Varga-Csikász Csenge: $A$ drámapedagógia hatása a tanári kompetenciák alakulására

\section{Section V. / V. Szekció : \\ TALENT DEVELOPMENT AND \\ SPECIAL EDUCATION / \\ TEHETSÉGGONDOZÁS ÉS GYÓGY- PEDAGÓGIA \\ Chairman / Szekcióvezető: \\ Fábián Fruzsina és Varga Boglárka}

Ábrók Anna: Sally Ride

Bacsur Tímea: Rita Levi-Montalcini

Barta Erika Odett: Telkes Mária

Barta Zsuzsa: Dorotby Hodgkin

Borbélyné Bacsó Viktória: Fiziłkai Innovációs Kutatómühely

Dorogi Kiara Dominika: SNI gyermekek elfogadása a magyar köznevelésben

Fábián Fruzsina és Varga Boglárka: Tanulásban akadályozott gyermekek vizsgálata zenei területen

Fucskó Mónika: Az intézményben élö fogyatékos személyek önálló életvitelének elösegitése

Hegedűs Renáta Ildikó: $A$ „torzszülöttek”-rôl alkotott mentális kép a középkorban

Hegedûs Roland: Különleges bánásmódot igénylö tanulók teljesitménye

Horváth László: A Csáti Refi program tapasz̧talatai

Hrubóczki Orsolya: Tamulásban akadályozott fiatalok továbbtanulási és elhelyezkedési lehetöségei

Kiss Zsófia: Nicole-Reine Hortense Lepaute

Kovács Loretta: Linda Buck

Menyhárt Tímea: Artemiszia

Mező Katalin: Hölgyek a tudományban

Mező Ferenc és Mező Katalin: S.M.ART School, Measurement and Art (A new innovative measurement system of pupils' cognitive and noncognitive characteristics)

Mező Ferenc: Innovációs Stúdium

Mező Kristóf Szíriusz: A jövő autói

Molnár Alexandra: Motiváló módszerek a tanulásban akadályozott gyermekek tanitása során

Németh Dávid László: Tehetséggondozás, program a programban

Németh László: A Csáti refi program tehetséggondoró aspektusai 
Parlagi Csenge Panna: Susan Adele Greenfield

Parrott Gábor: Hulladékkeezelés

Rácz Vivien: Alexandriai Hüpatia

Szabó Dániel Dénes: Müanyag úgrahasznositás háztartásainkban

Szakács Erika Tünde: Rosalind Franklin

Tóth Alexandra: Mileva Marić

Tóth Virág Rebeka: Barbara McClintock

Varga Boglárka, Fábián Fruzsina: Tanulásban akadályozott gyermekek vižsgálata vizuális területen

Váróczy Viktória: Müvészeti alkotások befogadása pilote projekt súlyosan halmozottan sérült személyekekel

Zsemján Eszter: A tanulásban akadályozottak integrált, inkluziv nevelése, oktatása SzabolcsSzatmár-Bereg Megyében

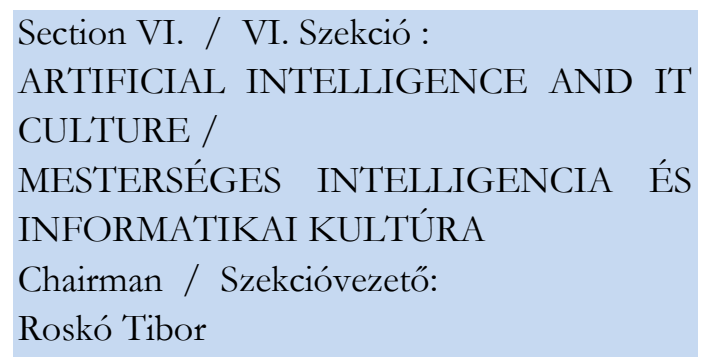

Bátfai Norbert, Csukonyi Csilla, Győri Krisztina és Papp Dávid: Minecraft az oktatásban

Csukonyi Csilla és Papp Dávid: Sportpszichológus vagy esportpszichológus? - A sportpszichológia szerepe az esportban

Erdős István: A mesterséges intelligencia jogbölcseleti vonatkozásai

Kovács Bence és Tóth János: Fog Computing A biztonságos felhö
Krek Norbert: Egy letünt müfaj újjáéledése - $A$ klasszikus szerepjáték müfaji konvencioinak alakulása a kéteares években

Ládiné Szabó Tünde: Storyline - Kerettörténet a Tankocka használatával, avagy kalandozás a Tankocka szigetre!

Pénzes Evelin: Fraktálok

Peter Pšenák: Piaci kockáąat és sqámszuerüsitése az $R$ szoftverrel

Pšenáková Ildikó: Ne hagyd magad becsapni!

Rácz Réka: Az internetfüggőség vizsgálata kvalitativ módszerekekel

Roskó Tibor: Mesterséges intelligencia fejlesztések három év távlatában

Szűcs Éva: Általánositott hatványösszeg-polinomok

Section VII. / VII. Szekció :

ART AND HISTORY /

MÜVÉSZET ÉS TÖRTÉNELEM

Chairman / Szekcióvezető:

Varga Imre Solt

Filip Anna Réka és Zalai Eszter: Figyelmi fókusz vizsgálata zene hallgatása közben

Gődér Attila: „Mert épen a közbátorság a társaságnak legelsó és legföbb czélja”. A republikánus beszédmód sajátos megjelenése egy elfeledett szerzó, Sasku Károly érvelésében

Kispál Dániel: Az irodalomtanitás belyzete hazánkban a 20. század elején

Kiss Milán: A posztmodern szinhbáz.

Kövér József: Feno és a genotipus története a müvészi szubjektum számára 
Lengyel Emese: Az operett-tánc problémája a szocializmusban I. rész - Megjegyzések Roboz Agnes Táncmüvészetben megjelent cikekeihez.

Lengyel Emese: Gulyás Menyhért színigazgatói tevékenysége Nyíregyházán

Lengyel Erik: Prelüd múfajának kiteljesedése marimba darabokban

Mátyus Magdolna: „Kettős tükör”: A mese és a gyermeki lélek

Mező Péter Dániel: Zrinyi Miklós: Srigeti vesz̨edelem

Nagy Kristóf: Görgey Istuán tevékenysége testvére, Artúr védelmében. Az elsö tanulmány: a móri csata.

Ozsváth Eszter Judit: Újrafestett bolygó: A kelimaváltozás ábrázolása a kortárs utcamüvészetben

Pájer Szabolcs: Az Est-lapok sajtótörténeti vizsgálata

Papp Fruzsina: London gengszter-hercegei: A Kray-fivérek mitosza

Pavlovics Zsófia: A prométheuszi magatartás camus-i értelmezése

Polyák Enikő: $A z$ idegenségkutatás távlatai $N e$ meth László Irgalom címü regényében

Réti Tamás: Crövek Erna (1899-1983) a karizmatikus zongoratanár (kutatási terv)

Sebők Balázs: „Enni, inni tudunk, de gyakorlatot végrehajtani nem”. A Munkásórség felállitásának kezdeti nehézségei Salnok megyében

Székely Csilla Imola: Kokas Klára gyermekekeról alkotott felfogásának legfontosabb aspektusai

Szolyka Hajnalka: Panteonizáció Kazinczy Ferenc életmüvében - a zempléni vitézek

Tóth Lilla: Megragadható pillanatok az impressziók bullámaiban

Varga Imre Solt: Luxemburgi Zsigmond huszita hadjáratainak elsô fele (1420-1422) és a hadjáratokat befolyásoló földrajzi tényező́k
Section VIII. / VIII. Szekció :

FAMILY, COMMUNITY, LAW AND ECONOMY /

CSALÁD, KÖZÖSSÉG, JOG ÉS GAZDASÁG

Chairman / Szekcióvezető:

Mező Lilla Dóra és Virág Ádám

Ábrók Kamilla: A véleménynyilvánitás szabadságánake aktuális kibivásai a munkajogban

Balogh Dóra: Tervezôi magatartás és értékkeözvetités

Bokor Tünde: Hargita megyei magyarok: a nagygalambfalvi lakóközösség identitástudata

Gönczi Barbara és Kincses András: Az Uber napjainkban

Herdon István: A joggal való visszaélés tilalmának aktuális kérdései a munkajogban

Kanyuk Petra Ágnes: A költségvetési csalás szabályozástörténetének alakulása az uniós elvárások tükerében

Konkoly Enikő Bianka: INTERREG IVC Interregionális együttmüködés 2007-2013 között az Európai Unióban

Kovács Lajos Péter: Bironyitási eszköröo a büntetôeljárásban

Kukucska Zsuzsa: Mozaikcsaládok - avagy a szakaszos monogámia vizsgálata

Laki Ildikó: A társadalmi illeszkeedés és beilleszkedés kérdései napjainkban

Loncsák Noémi: Gyerekes háztartások squgénysége a határainkon túl

Mászlai Tamás: Innováció és vállalkozás - létrehozás és fejlesztés

Mező Lilla Dóra: „Változnak az idők”” a nook belyzete Ghánában

Molnár Fanni: A javitóintézeti nevelés komplexitása 
Németh János: Szankció a jobb jövóert? - A jóvátételi munka célja és tapasztalatai a hazai büntetéskiszabásban

Paládi Petra: $A$ dolmányos varjú társadalmi elfogadottsága

Sallai Balázs: Fegyelmi ügyek Debrecen közigazgatási bizottsága elött a Tanácsköztársaság bukása után

Szöőr-Fülöp: Ezüistgazdaság- Értékek rendszere és a munka értéke
Szűcs Boglárka: A fenntarthatóság fogalmának alakulása

Szücs Gábor: A vidéki nagyvárosok sportpreferenciáinak történeti módszertannal történö vizsgálata

Tóth Dalma: Az, „ezüstgazdaság” munkavégzését akadályozó tényező́k

Ujhelyi Nelli: Kortárs filantróp önkéntes segitségnyújtási formák és a közösségi média

Virág Ádám: A szociális szövetkęetek megszünése mögött álló háttértényező́k 